\title{
Mütoloogilise teksti konstrueerimise moodustest: slaavi rahvauskumused Kuu laikudest
}

\begin{abstract}
Aleksandr Gura
Teesid: Täiskuu pinnal nähtavaid tumedaid laike on slaavi rahvakalendris tõlgendatud mitmeti, kusjuures teemarühmade koondamisel võib täheldada nende osalist kattuvust. Artiklis antakse ülevaade slaavi rahvaste seas levinud selgitustest Kuu laikude päritolu kohta. Kuu laikudest rääkivate slaavi narratiivide võrdlev analüüs näitab teksti jagunemist erinevateks morfoloogilisteks elementideks, võimaldab teha kindlaks elementide vastastikuseid seoseid ja kombinatsioone, näidata, kuidas neist "monteeritakse" ja konstrueeritakse tekste erinevates piirkondlikes pärimustes, selgitada välja mütoloogilise teksti grammatilist struktuuri tervikuna.
\end{abstract}

Märksõnad: Kuu laigud, mütoloogia, slaavi rahvapärimus

Täiskuu pinnal nähtavad tumedad laigud on slaavi rahvakalendris saanud mitmeid tõlgendusi, mida võib koondada mitmesse osaliselt kattuvasse teemarühma.

\section{Kuu plekkide seletamine mustusega}

Esimene tõlgendusterühm (peamiselt bulgaarlastel, osaliselt ka makedoonlastel ja horvaatidel) on seotud lehma ja lehmasõnnikuga. Laigud Kuul on nende selgituste kohaselt kas suure udaraga lehm (Mazneva 1946: 109) või pirnipuu, mille sõi paljaks Jumala lehm, kellest selle tagajärjel sai Kuu (Stamenova 1977: 72). Kõige sagedamini on see aga lehma- või härjakoogi jälg. Kuust mööda läinud lehma jäetud koogi (Stamenova \& Koleva 1972: 108) sees määris end nõia poolt maale visatud Kuu (Stamenova 1977: 2) või visati lehmakook Kuule, et see ei paistaks nii eredalt (Stamenova 1977: 31; Stamenova \& Koleva 1974: 46; Popov 1994: 11; Hristova 1941: 117; Veltševa: 48; Jankovitš 1951: 109). Tavaliselt viskas sõnnikukoogi Kuule tütarlaps (sageli pruut), kes veetis aega koos armastatuga (Veltševa: 48), õmbles või kudus (Milenkova 1943: 131; Iva- 
nova 1937: 58; Araktšijeva 1939: 92; Penušliski 1969: 26; Maizner 1934: 152), töötas öösel põllul (Mazneva 1946: 108) või lõi ennast vee järele minnes ära vastu madalal rippuvat Kuud (Pentševa 1940: 128-129; Trifonova 1945: 158). Mõnikord on viskajaks Päike - kadedusest, et Kuu paistab temast eredamalt (Nenov 1939: 102; Mazneva 1946: 108; Stamenova \& Koleva 1972: 5, 55; Stamenova 1977: 6, 49, 72; Mihhailova 1985: 171; Popov 1994: 11; Krsteva 1943: 128129; Džordževitš 1958: 30; vrd ka Georgijeva 1983: 23; Vakarelski 1977: 414) või kättemaksuks selle eest, et Kuu temaga ei abiellunud (Mihhailova 1985: 151, Popov 1994: 11; Kasabova 1940: 122).

Bulgaarlased seletavad Kuu plekke ka käte pühkimisega Kuusse - see on taigna, mustuse või roojaga määrdunud käte jälg, mille jättis naine, kes pühkis madalal rippuva Kuu sisse käsi pärast taina sõtkumist (Georgijeva 1983: 23), mähkmete pesemist (Ilijeva 1941: 127) või lapse pepu pühkimist (Veltševa: 49; Stamenova \& Koleva 1974: 4; Georgijeva 1983: 23).

\section{Kuule sattunud inimesed}

Bulgaarlased ja osaliselt venelased näevad Kuu laikudes armunud poissi ja tüdrukut - enamasti vee järele minemas. Põhjas elavatel venelastel on need vee järele minevad poiss ja tüdruk (VGÜ, Ludnikova 1923: 3) või ämbreid kandev tüdruk (Belova 2004: 521), bulgaarlaste meelest on Kuu plekid ämbreid kandev tüdruk ja poiss armukohtingul (Trifonova 1945: 158), mõnikord aga ainult tüdruk kaelkookude ja ämbritega (Georgijeva 1983: 23; Georgijeva 1971: 21, Krsteva 1943: 128-129). Mõningate tõlgendusvariantide kohaselt annab tüdruk poisile ämbrist juua (Milenkova 1943: 132; Paševa 1983: 99) või suudleb teda (Pentševa 1932: 89). Poiss, piiga armastatu (Trifonova 1945: 158; Antšev 1980: 63; Fandkova 1937: 27), on mõnikord karjus (Mazneva 1946: 109), vaene (Pentševa 1932: 89) või tüdrukusse armunud sugulane (Paševa 1938: 99). Kaelkookudega tüdruku kujund Kuul on tuntud ka Volõonnia ukrainlaste seas (Belova 2004: 519).

Vene ja lõunaslaavi pärimuses figureerib sepp: venelastel taovad kaks seppa Kuu peal tähti (Koltšin 1899: 7); ${ }^{1}$ serblaste selgituste kohaselt on Kuul pidupäevadel võtmeid sepistav sepp (Jankovitš 1951: 109); horvaatidel sepp Vid (vrd püha Vitus kui seppade kaitsepühak mõnes lõunaslaavi pärimuses (Tolstaja 1995: 369)), kes on endale kuradi õpipoisiks võtnud (Džordževitš 1958: 31); Bosnia moslemitel teiseusuline sepp, kes katkestas alasile kopsimise selleks ajaks kui mulla kutsus minaretist palvusele (Džordževitš 1958: 31); serblastel mustlassepp, kes lööb haamriga alasile, mistõttu Kuu paistab tuhmimalt kui päike (Džordževitš 1958: 31; Jankovitš 1951: 109). 
Mustlane esineb ka teiste lõuna- ja idaslaavlaste Kuu laikudega seotud uskumustes. Horvaatide ja bosnialaste pärimuse kohaselt on Kuu peal näha mustlane alasi ja haamriga, millega ta on tüli käigus tapnud oma talupojast ristiisa (Džordževitš 1958: 31-32); bulgaarlaste uskumuses esineb poodud mustlane (Vakarelski 1977: 414) või mustlane peegliga, mille ta täiskuu ajal meie peale suunab, aga muul ajal kõrvale keerab (Georgijeva 1983: 23; Vakarevski 1977: 414, vt ka Popov 1994: 11); venelaste uskumuses figureerivad Kuul aga juut ja mustlane (AKTE, Volgogradi oblast).

Järgmine bulgaarlaste ja lääneslaavlaste seas levinud selgitusterühm on seotud varguse, varga ja varastatuga. Bulgaarlaste meelest on laigud Kuul tekkinud meest, mille Kuu varastas (Georgijeva 1983: 23); jälg, mille jättis sõnnikukook, kui vargaplika sellega Kuud lõi, et too ei segaks teda varastamast (Vglenov 1936: 16) või poiss varastatud adraga (Georgijeva 1983: 23; Vakarelski 1977: 414). Tšehhid ja poolakad näevad Kuul herne- või sõnnikuvarast (Afanasjev 1944: 25; Wasilewski 1989: 190-191); sorbid naist, kel on seljas korv varastatud munadega (Czerny 1895: 56); tšehhid varast jõululaupäeval näpatud puusületäiega (Afanasjev 1944: 251); Saksa piiri ääres elavate poolakate arvates tähistavad laigud varast pundi herneväätidega, millega too kattis Kuu, et see ei takistaks teda varastamast (Wasilewski 1989: 191).

Mitmes tõlgenduses, eriti poolakate omades sisaldub pühade ajal töötamise motiiv. Kuul on näha inimesed, kes töötasid kas pühapäeval või pühade ajal: serblastel puuraiuja, kes pühapäeval metsas puid tegi või pühapäeval kuuvalgel kudunud tütarlaps (Jankovitš 1951: 109); poolakatel talupoeg, turjal haokubu või puud (Szyfer 1975: 145; SSS 1996: 194, PAE kaart), herneid külvav talumees (Wasilewski 1989: 191), härgadega kündev mees (Szyfer 1975: 145, SSS 1996: 194), ${ }^{2}$ vanaeit võid tegemas (Wasilewski 1989: 190; Szyfer 1975: 145), astjas tainast sõtkumas (Wasilewski 1989: 190; PTA EI 1145-I: 2), leiba küpsetamas (Szyfer 1975: 145, SSS 1996: 194), kudumas või ketramas (Wasilewski 1989: 190; PAE kaart; vt ka Kuchta 1926: 46).

Mõnes variandis figureerib ketraja või õmbleja: polaabi slaavlastel ketrab naine Kuul lõnga, mis suve lõpus ämblikuvõrguna maale langeb (Afanasjev 1994: 275; Kuchta 1926: 46); bulgaarlastel ja serblastel ketrab tütarlaps koonalt (Stamenova \& Koleva: 108; Jankovitš 1951: 109); tšehhidel ja poolakatel ómbleb prohvet Sibylla särki, tuues iga päevas tehtud pistega lähemale maailmalõppu (Kuchta 1926: 46).

Poola ja sorbi ettekujutuste kohaselt on Kuul näha talumeest sõnnikuga (või õlgedega): talumees hoiab labidat, millega ta viskas jõulude ajal sõnnikut välja (Siarkowski 1885: 66); talumees veab pühapäeval sõnnikut välja, viskab seda viglaga laiali (Kolberg 1962d: 69; PTA EI 1145-I: 2, SSS 1/1: 194; Kolberg 1962c: 5, PAE Ülem-Sorbi, Czerny 1895: 56); selle talumehe pea või nägu (Czerny 
1895: 56), aga ka jalad (Kolberg 1962a: 91); talumees, kelle saatan on hargi otsa poonud selle eest, et mees jõulude ajal viglaga õlgi soputas (PTA EI 1796: 6).

\section{Karistus tapatöö eest}

Eriti laialt on slaavlaste seas levinud pärimused, mis on seotud kahe venna ja vennatapuga. Kuul on nende seletuste kohaselt näha kaks venda (sageli Kain ja Aabel). Vennad rebivad vara jagades teineteise käest katelt (bulgaarlastel Kunov 1940: 117), nuia (ukrainlastel) või hangu (poolakatel - Kolbuszewski 1895: 171). Vend tapab venna (sageli rikas vend vaese) heina- või põhukuhja pärast (Polesje ukrainlastel ja valgevenelastel - Belova 2004: 509; Agapkina 1993: 154), kättemaksuks tema maalt niidetud heina eest (Taga-Karpaatia ukrainlastel - Belova 2004: 519), maa ja muu vara jagamisel (ukrainlastel ja valgevenelastel - Belova 2004: 518-519). Üks vend torkab teise kogemata viglaga läbi vihkude laadimisel (bulgaarlastel - Mihhalev: 181), laadides heina maha või tõstes seda loomadele ette jõulude, uue aasta, kolmekuningapäeva või lihavõtete ajal (ukrainlastel - Zaglada 1929: 137; Belova 2004: 516-517; Agapkina 1993: 154; Afanasjev 1994: 251). Kain tapab Aabeli (vend tapab venna): kõige sagedamini (idaslaavlastel ja osaliselt poolakatel) torkab ta hanguga surnuks (Zelenin 1991: 424; Kuchta 1926: 41, 42; Dal 1957: 922; Bernštam 1988: 275; Afanasjev 1994: 252; Agapkina 1993: 153-154, 155, Belova 2004: 505-510, 511, 515; Nikiforovski 1897: 219; Federowski 1897: 149; Moszyński 1928: 156; Kuchta 1926: 45; Savtšenko 1906: 106; Fischer 1909: 328; SSS 1996: 145; Kolbuszewski 1895: 171; Szyfer 1975: 145); harvem (nt Taga-Karpaatia ukrainlastel) torkab teibaga läbi (Belova 2004: 509), lööb kirvega maha (venelastel ja valgevenelastel - AKTE; Agapkina 1993: 153; Belova 2004: 509, 516), tapab haamri või kaelkookudega (venelastel - AKTE), aga ka noa või mõõgaga (serblastel, ukrainlastel ja osalt Polesje valgevenelastel - Jankovitš 1951: 108; Agapkina 1993: 153; Belova 2004: 516). Venelaste uskumuse kohaselt kannab Kain tapetud Aabelit (venda) seljas või tassib turjal Kuu pealt merre (AKTE; Zelenin 1914: 186; Belova 2004: 506, 514; Agapkina 1993: 155). Poolakatel sooritab Kuu peal vennatapu pattu kahetsev Kain koos Aabeliga ohverdamise (RKA 8643 nr J11). Mõnikord (lõuna- ja idaslaavlastel) on Kuul üksnes vennatapu eest karistust kandev Kain (Džordževitš 1958: 31; Vakarelski 1977: 414; Georgijeva 1983: 23; Penušliski 1969: 25-26; Markevitš 1860: 77; Kuchta 1926: 41; Afanasjev 1994: 251), venelaste juttudes on ta mõnikord kirvega (Belova 2004: 509), ukrainlaste pärimuses on Kuul ka Aabel kui Kaini ohver (Belova 2004: 506). Lisaks vennatapule võib mõningates Polesje uskumustes kohata ka teiste isikute tapmist: mees torkab naise hanguga läbi (Belova 2004: 520), isa hoiab 
poega vigla otsas (Belova 2004: 520) või on isa poja vigla otsas (PA, Žõtomiri oblast) poeg pussitab isa (Belova 2004: 520), inimene hoiab karu hangu otsas (Belova 2004: 521).

\section{Piiblitegelased, pühakud ja ajaloolised isikud}

Sageli seostatakse Kuu laike piiblitegelaste ja pühakutega. Nii on idaslaavlaste ettekujutuse kohaselt Kuul näha Aadam ja Eeva (AKTE; Belova 2004: 511; vrd nt Tšernigivi oblastis hoiab Aadam Eevat hangu otsas, Belova 2004: 511) või Jumal esimesi inimesi leivaga toitmas (Dal 1957: 922), bulgaarlaste arvates keedavad Aadam ja Eeva katlas piima (Telbizov \& Vekova-Telbizova 1963: 175). Serblased seevastu näevad Kuul evangelist Matteuse ikooni (Džordževitš 1958: 31; Jankovitš 1951: 108); Taga-Karpaatia ukrainlased Ristija Johannese pead (Belova 2004: 514); Pinski ümbruse valgevenelased inimest Ristija Johannese maharaiutud peaga või poja ohverdanud Aabrahami (Belova 2004: 513). Taga-Karpaatia ukrainlased mainivad ka vendi Eesavit ja Jaakobit, kellest üks on viglaga, millega ta oli tapnud oma isa (Belova 2004: 513). Ida-Polesje ukrainlaste meelest on Kuul märtritest vennaksed Asarija ja Anani (Belova 2004: 514); Polesje ukrainlaste ja venelaste meelest prohvet Ilja (Eelias) vankril või hobusega (Belova 2004: 511, vrd ka Bresti oblastis Ivanovski rajoonis vennad Ivan ja Lasar, üks torkab teist hanguga - Belova 2004: 511); poolakatel piksest ehmunud püha Jüri (Kuchta 1926: 49; Gustawicz 1901: 134-135) või püha Stefanus, kellele on tehtud ülesandeks juhtida Kuud (Wierzchowski 1890: 189), aga venelastel peaingel Miikael või Gaabriel, kes valitsevad Päikest ja Kuud (Bernštam 1988: 275). Poola uskumuste kohaselt mängib püha Jüri Kuul viiulit või lautot (Kolberg 1963b: 196; Ciszewski 1887: 3; Gustawicz 1901: 134-135; Udziela 1890: 133; Kolberg 1963a: SSS 1996: 194; Kuchta 1926: 48), ${ }^{3}$ tšehhide meelest musitseerib seal Taavet viiulil või harfil (Rihlik 1928: 213; Afanasjev 1994: 251), slovakkide arvates mängib harfi kas Aabram või Taavet, paludes Jumalal tõsta ema põrgutulest (Belova 2004: 512; Eljasz-Radzikowski 1899: 248); ülemsorbide uskumuses mängib moosekant Jumalale, jumalaemale või pühale vaimule, et päästa oma vanemaid põrgust (Haupt \& Schmaler 1953: 387).

Mõnes uskumuses figureerivad ingel ja saatan. Ukrainlaste ja bulgaarlaste tõlgenduses märgivad Kuu laigud patustanud inglit (Belova 2004: 511), kelle Jumal on ära neednud ja kellest on saanud saatan (Georgijeva 1983: 23), serblastel taevast langenud ja kuradiallikast vett joonud inglit, kelle kurat pärast Kuu peal kätte sai ja lõi talle labajalga haava (Maizner 1934: 100-101; Džordževitš 1958: 31; Kulišitš jt 1970: 201; Jankovitš 1951: 109), bulgaarlastel kurat 
(Vakarelski 1977: 414), bosnialastel Jumala poolt risti löödud aheldatud saatan (Džordževitš 1958: 31; Jankovitš 1951: 109).

Lõpuks seletatakse laike Kuul ka ajalooliste isikute viibimisega seal. Nii on poolakate ettekujutuse kohaselt Kuul näha Krakovi nõid Tvardovski (Kuchta 1926: 49; Wójcicki 1972: 118; Kolberg 1962b: 228; SSS 1996: 194; Kolbuszewski 1895: 171), kes suitsetab piipu või teeb võid (SSS 1996: 194); Tvardovski keha vigla otsas hoidev kurat (SSS 1996: 194) või kuningas Vladislav, kes hukkus 1444. aastal sõjas türklastega (Kolberg 1962c: 4-5; Kuchta 1926: 46). Venelased samastavad Kuu laike Peeter I või kahe tsaariga (Ivan Julm ja Peeter I) (AKTE), serblased seevastu kuningas Marko tähnilise hobuse peaga (Džordževitš 1958: 31; Kulišitš jt 1970: 201; Jankovitš 1951: 108).

\section{Muid seletusi}

Täiesti eraldiseisva rühma moodustavad aga mõned uskumused. Kašuubide meelest on Kuule jäljed jätnud määre. Määriti selle vankri taevaratast (Kuud), millega peaingel Miikael jälitas kuradit taevase sõja ajal (Sychta 1967-1976 (3): 281). Serblaste arust paistavad Kuul alaks kutsutud maotaolise koletise hammustuste jäljed (Kulišitš jt 1970: 4), bulgaarlaste arvates jättis jäljed riie, millega tüdruk nühkis tuhmimaks Kuu eredust (Javašev 1937: 182-183). Bulgaarlastel on levinud ka uskumus, et Kuu peal on hoopis puuraiduri pea, puuraidur oli seesama, kes kuhjas Kuule küttepuid sel ajal, kui Kuu veel maa peal käis (Mazneva 1946: 108). Makedoonlased usuvad, et Kuul on hiljuti külas surnud vanamehe nägu (Afanasjev 1994: 252; Kuchta 1926: 43); serblaste meelest on seal koera pea (Kulišitš jt 1970: 201; Jankovitš 1951: 108); venelaste arvates herneste kuivatamise alus (AKTE, Arhangelski obl), aga ka inimene, kes on otsustanud Kuu üle võõbata, et see nii heledasti ei paistaks (O. Belova ülestähendus Karjalast, Kemi raj). Polesje ukrainlaste uskumuse kohaselt on Kuul inimene vikati ja rehaga (Belova 2004: 521), bulgaarlaste arvates viljalõikajad põllul või karjus lambakarjaga (Ivanova 1937: 58) jne.

\section{Mütoloogilise teksti moodustumisest}

Nagu põgusast ülevaatest näha, esinevad igas loetletud teemarühmas korduvad elemendid, mis moodustavad omavahel erinevaid kombinatsioone ja piirkondlikke vasteid. Neist kujuneb mütoloogiline tekst, mida võib esitada lihtsalt uskumusena, sagedasti tähendussõnade vormis (nt vend tappis venna), aga ka arenenud süžeega vabas vormis jutustusena, sageli etioloogilise legendina, mis tihti sisaldab apokrüüfilisi motiive. 
Vaatlusalune mütoloogiline tekst koosneb mitmetest erilaadilistest semantilistest elementidest. Kõigepealt tegelaskujud (sepp, kuningas Taavet, Kain, ketraja, prohvet, varas, teiseusuline, karjus, ingel, kurat, poodu, lehm jt), sageli esinevad nad paarikaupa: kaks venda, Kain ja Aabel, kaks vaderit, kaks seppa, kaks keisrit, isa ja poeg, mees ja naine, poiss ja tüdruk, juut ja mustlane, Aadam ja Eeva jne. Tõlgenduste eri variantides figureerivad ühed ja samad esemed (enamasti tegelaskujude juurde kuuluvad esemed): viglad, kaelkoogud, vasar, katel või vaskämber, sõnnik, puud või hagu, heinad või õled, viljavihud, hernes, leib või tainas. Esindatud on ka korduvad omadused (näiteks vaene ja rikas, vennad või peigmehed, Kuu hele valgus, madalal rippuv Kuu), tegelaskujude vastastikused suhted (poisi ja tüdruku ning Kuu ja Päikese armu- või abielusidemed, tegelaskujude paarilisus), ajalised määratlused (püha või pühapäev töö või varguse ajal) ja lõpuks tegevused - funktsioonid ja olukorrad (Kuu juhtimine, Kuu viskamine Maa peale, ketramine, kudumine või õmblemine, vee järel käimine, muusikariista mängimine, seljas kandmine, tapmine, vargus, jaht, vee joomine).

Seejuures on samad semantilised elemendid erinevates piirkondlikes tavades sageli üksteisega seotud erinevalt, vormides teksti dialektilisi variante ja moodustades Kuu laikude käsitlemisel omamoodi semantilise välja. Nii esineb haamer sepa töövahendina ja tapariistana; kaelkoogud vee järele mineva tüdruku kandevahendina ja tapariistana; vigel talumehe tööriistana (viglaga viskab ta sõnnikut laiali) ja tapavahendina (Kain torkab viglaga Aabelit) või koguni hukkamiskohana (vigla otsa poodud talumees). Sõnnikut võib kohata mitme tegevuse juures: seda kaevatakse labidaga, visatakse hanguga laiali, veetakse välja, varastatakse, visatakse Kuu peale, Kuu määrib end sellega). Hernest kuivatatakse, varastatakse, pannakse maha, kantakse seljas, sellega kaetakse Kuud. Katla (või vaskämbriga) minnakse vee järele, seda üritavad kaks venda omavahel jagada, Aadam ja Eeva keedavad selles piima. Ingel ja kurat esinevad ühes ja samas tegevuses nii subjekti kui ka objektina: kurat jälitab inglit, peaingel Miikael jälitab kuradit. Seljakandamina figureerivad mitmed esemed ja tegelaskujud: munakorv, herneväädid, haokubu, puud, tapetud Aabel. Vargus on nii tegevus (inimese või Kuu toiming), tegelaskuju (varast või vargaplikat) iseloomustav omadus, aga see on tunnuslik ka mitme eseme puhul (varastatud munad, mesi, sõnnik, hernes, adratera). ${ }^{4}$

\section{Tekstielementide geograafia}

Eraldi analüüsi ja interpreteerimist vajab esiletoodud tekstielementide geograafiline levik. Osundame siinkohal vaid areaali seisukohalt kõige ilmekamatele neist: viglad, lehm (härg), lehma (härja) sõnnik, Kuu hele valgus, va- 
sar, kaelkoogud, rikas/vaene sepp, vee järel käimine, sõnnik, ketramine (kangakudumine, õmblemine), vargus, töötamine pidupäeval, herned.

Materjalist selgub terve rida kokkulangevusi slaavlaste pärimustes, sealhulgas ida-, lääne- ja lõunaslaavlastel: 1) idaslaavlastest esineb vigel poolakatel ja bulgaarlastel; Kuu hele valgus lõunaslaavlastel, venelastel ja poolakatel; lehm (härg) ja nendega seotu lõunaslaavlastel, poolakatel ja ukrainlastel; 2) kaguslaavlaste pärimuses võib kohata vasarat venelastel, valgevenelastel, bosnialastel ja horvaatidel, kaelkooke venelastel, ukrainlastel ja bulgaarlastel; vastandpaar rikas/vaene esineb ukrainlastel, valgevenelastel ja bulgaarlastel; sepp serblastel, bosnialastel, horvaatidel ja venelastel; 3) edelaslaavlastest kohtame sõnnikut bulgaarlastel, makedoonlastel, poolakatel ja sorbidel; ketramist (kangakudumist, õmblemist) bulgaarlastel, makedoonlastel, serblastel, poolakatel ja tšehhidel; vargust tšehhidel, poolakatel, sorbidel ja bulgaarlastel; 4) loodeslaavlaste pärimuses esineb töötamine pühade ajal poolakatel, sorbidel ja ukrainlastel; herned tšehhidel, poolakatel ja venelastel.

Lisaks loetletud semantilistele elementidele võib mõningates juttudes täheldada ka tegelaskujude Kuule sattumise eri viise. Mõnikord satub tegelane sinna ise. Näiteks serblaste pärimuses jookseb ingel Kuule teda jälitava kuradi eest (Maizner 1934: 100-101; Džordževiťs 1958: 31; Jankovitš 1951: 109); poolakatel hüppab püha Jüri sinna piksehirmust (Udziela 1890: 75; Kuchta 1926: 49; Gustawicz 1901: 134-135); venelastel jookseb Kain, tapetud Aabel seljas, kaugele läände, kus Kuu puudutab Maad, ja siirdub sealt Kuule (Belova 2004: 506). Mõnikord kasutab tegelaskuju Kuule jõudmiseks erivahendeid: põhja-vene uskumuse kohaselt tõusis Kuul nähtav ämbritega tüdruk sinna talsipühade õhtul mööda raudset ketti (Belova 2004: 521). Aga vahel aitab tegelaskujudel enda pinnale jõuda Kuu ise: sloveenidel ja horvaatidel tirib Kuu enda pinnale laiskvorstist töömehe ja tüdruku, kes öösel põllul töötasid (Kuchta 1926: 43); põhjapiirkonna venelastel laskuvad kuukiired taevast ja tõmbavad justkui londiga Kuule poisi ja tüdruku, kes tema poole vaatavad (VGÜ, Ludnikova 1923: 3) või kleepub inimene Kuu külge, kui on otsustanud seda värvida (O. Belova üleskirjutus Karjalast, Kemi raj). Tegelaste Kuule teisaldamisel osalevad ka kõrvalised jõud: poolakatel haarab vikerkaar kõlvatut elu elanud tüdruku ja kannab ta Kuule (Kuchta 1926: 45); kurat viib sinna Tvardovski (Wójcicki 1972: 117-118; Kolbuszewski 1895: 171) või kukub Tvardovski Kuule pärast seda, kui jumal ta taevast alla lükkab (autori üleskirjutus Chełmi piirkonnast); lääneukrainlastel tuleb ingel maale ja toimetab Kuule Aabeli (Belova 2004: 506); venelastel saadab Aabeli Kuule jumal (Belova 2004: 506); horvaatidel paigutab püha Peetrus Kuule sepa (Džordževitš 1958: 31; Jankovitš 1951: 109); bulgaarlastel tõstab jumal sinna pruudi, kes pahandas Kuuga sellepärast, et too oli liiga madalal maa kohal (Trifonova 1945: 158) või tõstab võlu- 
rist isa nõiavõimete abil Kuule tütre, kes on kallimaga suudelnud (Pentševa 1932: 89). Bulgaarias on teada ka uskumus,mille kohaselt kanduvad pärast surma Kuule vendade hinged (Mihhalev: 181).

\section{Ümberpaiknemise põhjendused}

Lõpuks sisaldavad tekstid sageli ka motiveeringut. Kuulaikudest rääkivates pärimustes ja nendega sageli seostuvates juttudes inimesest Kuul esineb sinna paigutumise põhjusena kõige sagedamini karistus: tapmise, varguse, ahnuse, pühade ajal töötamise, vanemate tahtele mitteallumise, kuradiga ühendusepidamise, kõlvatu käitumise eest enne abiellumist, võimaliku verepilastuse, Kuu vandumise ja needmise, tema heleduse kallale tungimise eest, aga ka Kuu põrnitsemise keelu rikkumise eest jne. Erinevad on aga karistamise eesmärgid: kuradi endale õpipoisiks võtnud sepp ja vaderi tapnud mustlane on pandud sinna kogu maailmale vaatamiseks ja hoiatuseks (Džordževitš 1958: 31-32); isale suhtes sõnakuulmatu tütar selleks, et tema salajane armastus saaks ilmselgeks (Pentševa 1932: 89); Kain, et inimesed näeksid tema karistust ega tapaks üksteist (VEM > Ant SPM: 1; VEM > Kamanin: 236; Belova 2004: 505; Kuchta 1926: 41), aga ka selleks, et Kain näeks kõiki öiseid tapmisi ja väriseks hirmust (makedoonlaste selgitus, Tsepenkov 1894: 83; Penušliski 1969: 25-26; Kuchta1926: 40-41), et Kain "kataks" ja "avaks" Kuud, st muudaks Kuu faase (venelaste selgitus, VEM, Kamanin: 236-237). Kuule võib sattuda ka needuse tagajärjel (Mazneva 1946: 109; Stamenova \& Koleva 1972: 108; Tsepenkov 1894: 83) või pühakute ülesandel Kuud juhtima (Wierzchowski 1890: 189).

Harvem tähendab Kuule tõstmine jumala autasu: võõra usu austamise eest saadeti bosnialaste pärimuses sinna näiteks võõrausuline sepp (Džordževitš 1958: 31); inimeste abistamise eest ülendati sinna vennad Pjotr ja Nikola (AKTE, Arhangelski obl); surematuse ja igavese nooruse saavutamiseks pääses ukrainlaste selgituse kohaselt Kuule laps, kelle ema oli ohverdanud, et päästa vastsündinud Kristus (Kuchta 1926: 39-40) või sloveenidel töömees, kes jättis oma viimase raha kerjustele, kellena esines jumal koos inglitega (Kuchta 1926: 40); poolakatel aga püha Jüri lohe võitmise ja inimeste tema hirmust vabastamise eest (Kolberg 1963b: 196). Inimese Kuule paigutamise eesmärk võib olla ka tema elu säilitamine või kuriteo ärahoidmine: jumal tõstab Kuule vaese venna, kel tekkis mõte tappa oma rikkurist vend (Piotrowicz 1907: 121).

Kuu laikudest rääkivate slaavi narratiivide võrdlev analüüs näitab teksti jagunemist erinevateks morfoloogilisteks elementideks, võimaldab teha kindlaks nende elementide vastastikused seosed ja kombinatsioonid, näidata, kui- 
das neist "monteeritakse", konstrueeritakse tekste erinevates piirkondlikes pärimustes, selgitada välja mütoloogilise teksti "grammatilist" struktuuri tervikuna.

Meie poolt vaadeldava teksti erinevad elemendid võivad kuuluda ka teistesse semantilistesse väljadesse. Sageli esinevad nad teisi astronoomilisi ja meteoroloogilisi objekte ja nähtusi puudutavates semantilistes mudelites. Nii võib vargust, heina ja vaderit kohata mõnes Linnuteed puudutavas uskumuses (vader varastab teise vaderi heina, vt nt Korenitš 1896: 146), viglast räägitakse ka madalal maa kohal rippuva taeva pärimuses (taevas torgatakse kogemata viglaga läbi), võitegemisest ja mustlasest seenevihma ja vikerkaart puudutavates pärimusjuttudes (vanaeit ja nõid teevad võid, mustlased abielluvad), ala ja hammustus esinevad kuuvarjutusest pajatavates pärimustes (ala sööb Kuu ära) jne.

\section{Kommentaarid}

1 Vrd ka kaks seppa (Bernštam 1988: 275), vasaraga mees (Belova 2004: 521).

${ }^{2}$ Vrd sama (härgadega kündev inimene), kuid pühale viitamata Valgevenes Polesjes (Moszyński 1928: 520).

${ }^{3}$ Vrd Suur-Poolas: inimene mängib harfi (Kolberg 1962c: 5).

4 Samasugust semantiliste elementide kombinatsioonide mitmekesisust võib täheldada paljudes teistes tekstides. Näiteks sisaldab öökulliga (vn sova) seotud uskumustest ja folkloorsetest tekstidest ilmnev semantiliste elementide valim muuhulgas ka selliseid motiive nagu surm ja lindude õgimine. Surm ilmneb öökulli karje tõlgendustes, surm iseloomustab öökulli seisundit päeva jooksul ja rakendub tema venna kaku puhul (pärimustes sureb; vn filin - nii nagu eesti keeles öökull ja kakk, tähendavad ka venekeelsed nimed сова ја филин tegelikult sama lindu - tlk). Seoses lindude õgimisega esineb öökull pärimuses kui subjekt (saab autasuks õiguse linde süüa) ja kui objekt (kanakull vohmib süüa kakupoegi kui kõige värdjalikumaid linnupoegi) (vt selle kohta Gura 1997: 568-586).

\section{Arhiiviallikad}

\section{AIF - Bulgaaria Teaduste Akadeemia Folklooriinstituudi arhiiv So- fias:}

Antšev, A. 1980 = Анчев, А. Фолклорни материали от село Винарско, Айтоски район, Бургаски окрьг. Архив на Институт за фолклор на БАН (София), АИФ № 215 I.

Mihhailova, K 1985 = Михайлова К. Фолклорни материали от с. Славеево, с. Драбишна, с. Свирачи и с. Орешино, Ивайловградска община, Хасковска област, Архив на Институт за фолклор на БАН (София), АИФ I № 47-II. 
AKTE - Uurali Riikliku Ülikooli vene keele ja üldkeeleteaduse kateedri toponüümilise ekspeditsiooni astronoomiakartoteek [Астронимическая картотека топонимической экспедиции Уральского гос. университета, кафедра русского языка и общего языкознания. Екатеринбург].

\section{ArhEIM - Bulgaaria Teaduste Akadeemia Etnograafia Instituudi muu- seumi arhiiv Sofias:}

Georgijeva, I 1971 = АрxЕИМ 576-II, Георгиева, И. Народен мироглед (материали). Бургаски окр., Варненски окр., Силистренски окр. Архив на Етнографски институт с музей при БАН (София), № 576-II.

Georgijeva, I 1972 = АрxЕИМ 776-II, Георгиева, И. Народен мироглед. Благоевградски окрьг, район Петрички. Архив на Етнографски институт с музей при БАН (София), № 776-II.

Stamenova, Ž. 1977 = АрxЕИМ 878-II, Стаменова, Ж. А. Светоглед, народни знания и вярвания. (Материали от селата в Пловдивски район, на юг от p. Марица). Пловдивски окр., Пловдивски р-н. Архив на Етнографски институт с музей при БАН (София), № 878-II.

Stamenova, Ž. 1977 = АрxЕИМ 879-II, Стаменова, Ж. А., Колева, Т. А. Светоглед, народни знания и вярвания. (Материали от селата в Пловдивски район, на север от р. Марица). Пловдивски окр., Пловдивски р-н. Архив на Етнографски институт с музей при БАН (София), № 879-II.

Stamenova \& Koleva $1974=$ ApxЕИМ 880-II, Стаменова, Ж. А., Колева, Т. А. Светоглед, народни знания и вярвания. (Материали от селата в Карловски район). Пловдивски окрьг. Архив на Етнографски институт с музей при БАН (София), № 880-II.

Stamenova \& Koleva $1972=$ АрxЕИМ 881-II, Стаменова, Ж. А., Колева, Т. А. Светоглед, народни знания и вярвания. (Материали от селата в Карловски район). Пловдивски окрьг. Архив на Етнографски институт с музей при БАН (София), № 881-II.

PA = Venemaa Teaduste Akadeemia Slaavi Uuringute Instituudi etnolingvistika osakonna Polesje arhiiv. Moskva [Полеский архив отдела этнолингвистики и фольклора Института славяноведения РАН. Москва].

PTA EI = Varssavi Ülikooli Etnoloogia ja Kultuurantropoloogia Instituudi arhiiv [Archiwum materiaBów terenowych Zakładu Etnografii Instytutu Historii Kultury Materialnej]:

ArchIHKM 1145-I. Pow. Ostrołęka, w. Wach. [Üleskirjutuse autor märkimata.] 1953.

RKA = Jagielloński Ülikooli slaavi etnograafia kateedri arhiiv Krakówis:

Atlas kultury ludowej [Rahvakultuuri atlas]. [K. Mošinski programmiks kogutud materjalid]. Woźniak, J. Kultura duchowa, w. Tryńcza, gm. Tryńcza, woj. Przemyskie. 1988. Archiwum Katedry Etnografii Słowian Uniwersytetu Jagiellońskiego (Kraków), 8643. 


\section{RKS - Püha Kliment Ohridski nimelise Sofia ülikooli raamatukogu, akadeemik S. Romanski juhendamisel kirjutatud diplomitööde arhiiv:}

Araktšijeva 1939 = Аракчиева, М. Етнографско изследване на с. Враца Кюстендилско. Ркс 357.

Fandkova 1937 = Фандъкова, М. Етнографско изследване на с. Булчино, Айтоско. Pкс 322.

Hristova 1941 = Христова, Т. М. Етнографско изследване на с. Покровник, Горноджумайско, Софийска област. Ркс 1.

Ilijeva 1941 = Илиева, В. С. Етнографско изследване на село Голинци, Ломско. Ркс 163.

Ivanova 1937 = Иванова, М. М. Етнографско изследване на село Габаре, Белослатинско. Ркс 330.

Javašev 1937 = Явашев, Р. И. Етнография и говор на с. Сухиндол, Севлиевско. Pкс 277.

Kasabova 1940 = Касабова, Н. Етнографско изследване на българите от село Еникьой, Узункуприйско, преселени в село Синапово, Елховско. Ркс 281.

Krsteva 1943 = Кръстева, М. П. Етнографско изследване на с. Тагарево, Средецко. Ркс 91.

Kunov 1940 = Кунов, Д. С. Етнографско изследване на село Добролево, Ореховска околия. Ркс 259.

Mazneva, L. 1946 = Мазнева, Л. Х. Етнографско изследване на село Одърне Плевенска околия. Ркс 55.

Mihhalev = Михалев, Д. Т. Етнографско и езиково изследване на с. Белцов, Беленско. Ркс 367.

Milenkova 1943 = Миленкова, А. С. Етнографско изследване на село Добрина Провадийско. Ркс 187.

Nenov 1939 = Ненов, С. Н. Етнографско изследване на с. Китино - Омортагско. Ркс 286.

Paševa 1938 = Пашева, М. Етнографско и езиково изследване на село Невестино, Карнобатско. Ркс 83.

Pentševa 1932 = Пенчева, Н. А. Етнографско изследване на село Атанаскьой, Бургаска околия. Ркс 254.

Pentševa $1940=$ Пенчева, Н. И. Етнографско изследване на с. Етър и околните села, Габровско. Ркс 167.

Trifonova 1945 = Трифонова, В. Д. Етнографско изследване на с. Михалци Павликенско. Ркс 20.

Veltševa = Велчева, В. И. Етнографско изследване на село Зверино - Врачанско. Ркс 34.

Vglenov 1936 = Въгленов, М. Х. Изследване на бита, нравите, обичаите и говора на с. Сръбе, Севлиевско. Ркс 271. 


\section{VEM - Venemaa Etnograafiamuuseum:}

Kamanin, P. = Каманин, П. М. Поверья, заговоры, обряды, приметы. Роды и уход за ребенком. Болезни и их лечение. Летаргия. Представление о смерти. Погребальные обычаи. Почитание праздников. Российский этнографический музей, ф. 7 (Этнографическое бюро кн. В. Н. Тенишева), оп. 1, № 29. 58 л.

Ant SPM = Ант.CПM - Суеверные представления о мирозданиия. Демонология. Суеверия, связанные с бытом. (Новгородская губ., Череповецкий уезд) / / Российский гос. этнографический музей, ф. 7 (Этнографическое бюро кн. В. Н. Тенишева) оп. 1, № 798. 14 л.

\section{VGÜ - Venemaa Geograafilise Ühingu arhiiv:}

Ludnikova = Лудникова, А. Ф. Легенды, записанные в с. Оксино Печорского у. Архангельской губ. // Архив Русского Географического общества, ф. 1, оп. 1, № 130. 4 л. [1923].

\section{Kirjandus}

Afanasjev 1994 = Афанасьев, Александр. Поэтические воззрения славян на природу. Опыт сравнительного изучения славянских преданий и верований в связи с мифическими сказаниями других родственных народов. 3. Москва: Индрик [репринт].

Agapkina 1993 = Агапкина, Татьяна. "Несказочная проза” и паремия. Толстая, Светлана. \& Цивьян, Татьяна (toim). Славянское и балканское языкознание. Структура малых фольклорных текстов. Москва: Наука, lk 152-159.

Belova 2004 = Белова, Ольга (koost ja komment). "Народная Библия”: Восточнославянские этиологические легенды. Традиционная духовная культура славян. Публикация текстов. Москва: Индрик.

Bernštam 1988 = Бернштам, Татьяна. Молодежь в обрядовой жизни русской общины $X I X$ - начала XX в. Половозрастной аспект традиционной культуры. Ленинград: Наука.

Ciszewski, S. 1887. Lud rolniczo-górniczy y okolic Sławkowa w powiecie Olkuskim. Zbiór wiadomości do antropologii krajowej 11. Kraków, lk 1-129.

Czerny, Adolf 1895. Istoty mityczne Serbów Łuzyckich. [Tõlge sorbi keelest Grabowski, B.] Warszawa: Wisła [1895] 10, lk 54-97, 245-281, 531-563.

Dal 1957 = Даль, Владимир. Пословицы русского народа. Москва: Художественная литература.

Džordževitš [Djordjevic] 1958 = Ђорђевић, Тихомир. Природа у веровању и предању нашега народа. Књ. 1. Београд: СЕЗб (књ 71).

Eljasz-Radzikowski, S. 1899. Z folklorystyki słowackiej. Lud 5, z. 3, 4. Lwów:, lk 238255, 297-320. 
Federowski, Michał 1897. Lud białoruski na Rusi litewskiej. Materyjały do etnografii słowiańskiej zgromadzone w latach 1877-1891. 1: Wiara, wierzenia i przesądy ludu z okolic Wołkowyska, Słonima, Lidy i Sokółki. Kraków.

Fischer, A. 1909. Uzupełnienia Dähnhardta. Lud 15, z. 4. Lwów, lk 320-339.

Georgijeva 1983 = Георгиева, Иваничка. Българска народна митология. София: Наука и изкуство.

Gura 1997 = Гура, Александр. Символика животных в славянской народной традиции. Традиционная духовная культура славян. Современные исследования. Москва: Индрик.

Gustawicz, B. 1901 O ludzie Podduklańskim w ogólności, a Iwoniczanach w szczególności. (Cześć wtóra)). Lud 7, z 1-4, lk 43-54, 128-146, 241-256.

Haupt, Leopold \& Schmaler, Johann Ernst 1953. Volkslieder der Sorben in der Oberund Nieder-Lausitz. Anastatischer Neudruck. Berlin: Akademie-Verlag.

Jankovitš 1951 = Јанковић, Ненад. Астрономија у предањима, обичајима и умотворинама Срба. Српски етнографски зборник, књ. LXIII. Београд: Српска Академија Наука.

Koltšin 1899 = Колчин, А. Верования крестьян Тульской губернии. Этнографическое обозрение 3, lk 1-60.

[Kolbuszewski, E] E. K. 1895 Gwiazdy I grzyby w podaniach ludu. (Szkic etnologiczny). Lud 1, z. 6, 7, 8. Lwów, lk 168-178, 197-207.

Kolberg, Oskar 1962a. Kujawy 1. Dzieła wszystkie 3. Wrocław; Poznań.

Kolberg, Oskar 1962b. Krakowskie 1. Dzieła wszystkie 5. Wrocław; Poznań.

Kolberg, Oskar 1962c. W. Ks. Poznańskie 7. Dzieła wszystkie 15. Wrocław; Poznań.

Kolberg, Oskar 1962d. Lubelskie 2. Dzieła wszystkie 17. Wrocław; Poznań.

Kolberg, Oskar 1963a. Kujawy 3. Dzieła wszystkie 3. Wrocław; Poznań.

Kolberg, Oskar 1963b. Kieleckie 2. Dzieła wszystkie 3. Wrocław; Poznań.

Korenitš, S. 1896. Život, jezik i običaji Stupničana kraj Zagreba. Zbornik za narodni zivot i običaji Južnih Slavena 1. Zagreb, lk 119-151.

Kuchta, Jan 1926. Polskie podania ludowe o człowieku na księżycu. Lud II, 5 (25). Lwów \& Warszawa \& Kraków \& Poznań \& Wilno, lk 38-51.

Kulišitš \& Petrovitš \& Pantelitš $1970=$ Кулишић, Шпиро \& Петровић, Петар Ж. \& Пантелић, Никола. Српски митолошки речник. Београд: Нолит.

Maizner 1934 = Мајзнер, Milaн. Српске народне приповетке. СЕЗб, књ. L. "Расправе и грађа”, књ. 1. Београд: Српска краљевска академија, lk 95-154.

Marinov 1914 = Маринов, Димитьр. Народна вяра и религиозни народни обичаи. Сборник за народни умотворения, наука и книжнина 28. София.

Markevitš 1860 = Маркевич, Николай. Обычаи, поверья, кухня и напитки малороссиян. Киев.

Moszyński, Kazimierz 1928. Polesie Wschodnie. Materjały etnografuczne z wschodniej części b. powiatu mozyrskiego oraz powiatu rzeczyckiego. Warszawa. 
Nikiforovski 1897 = Никифоровский, Николай. Простонародные приметы и поверья, суеверные обряды и обычаи, легендарные сказания о лицах и местах. Витебск: Губернская типография.

PAE = Polski atlas etnograficzny. Instytut Historii Kultury Materialnej. Zakład Etnografii. Wrocław.

Penušliski (koost ja toim) 1969 = Пенушлиски, Кирил. Преданија и легенди. Скопје: Македонска книга.

Piotrowicz, S 1907. Znachorka i wróżka Jewdokia Bojczuk. Materyały folklorystyczne ze wsi Bortnik na Pokuciu. Lud 13, z. 2, 3. Lwów, lk 118-129, 216-232.

Rihlik 1928 = Рихлик, Євген. «Lud». Serja II. Tom V, zeszyt I-IV. Rok 1926 (144+XVIII). Етнографічний вісник 7. Київ, lk 213-215.

Popov 1994 = Попов, P. (vast toim). Родопи. Традициона народна духовна и социалнонормативна култура. София: Издателство на БАН.

Savtšenko 1906 = Савченко, И. Миросозерцание наших простолюдинов-малоруссов. Живая старина, lk 105-108.

Siarkowski, W. 1885. Materyjały do etnografii ludu polskiego z okolic Pinczowa. Zbiór wiadomości do antropologii krajowej 9. Kraków: Drukarnia Uniwersytetu Jagiellońskiego, lk 3-72.

SSS (stereotüüpsete sümbolite sõnastik) = Bartmiński, Jerzy \& Niebrzegowska, Stanisława (toim) 1996. Słownik stereotypów i symboli ludowych 1: Kosmos. Niebo. Światła niebieskie. Ogień. Kamienie. Lublin: UMCS.

Szyfer Anna 1975. Zwyczaje, obrzędy i wierzenia Mazurów i Warmiaków. Wyd. 2 poszerzone. Olsztyn (Rozprawy i materiały Ośrodka badań naukowych im. Wojciecha Kętrzyńskiego w Olsztynie, nr 50).

Sychta, Bernard 1967-1976. Słownik gwar kaszubskich na tle kultury ludowej 1-7. Wrocław \& Warszawa \& Kraków \& Gdańsk: Zakład Narodowy im. Ossolinskich.

Zaglada 1929 = Заглада, Ніна [Леоніла]. Побут селянської дитини. Матеріяли до монографії с. Старосілля. Матеріяли до етнольогії, І. Київ.

Zelenin 1914 = Зеленин, Дмитрий. Описание рукописей Ученого архива Императорского Русского географического общества. 1. Петроград: Императорское Русское Географическое Общество.

Zelenin 1991 = Зеленин, Дмитрий. Восточнославянская этнография. Москва: Наука. Telbizov \& Vekova-Telbizova 1963 = Телбизов, Карол \& Векова-Телбизова, Мария. Традиционен бит и култура на банатските българи. СбНУ 51. София: БАН.

Tolstaja 1995 = Толстая, Светлана. Видов день. Толстой, Никита (toim). Славянский древности. Этнолингвистический словарь 1. Москва: Международные отношения, $\mathrm{lk}$ 369.

Tsepenkov 1894 = Цепенков, М. Тълкувания на природни явления, разни народни вярвания и прокобявания. От Прилеп. Сборник за народни умотворения, наука и книжнина 11. София, $1 \mathrm{k}$ 73-84. 
Udziela, S. 1886. Materjały etnograficzne zebrane z miasta Ropczyc i okolicy. Zbiór wiadomości do antropologii krajowej 10. Kraków: Drukarnia Uniwersytetu Jagiellońskiego.

Udziela, S. 1890 Lud Polski w powiecie Ropczyckim w Galicyi. Zbiór wiadomości do antropologii krajowej 14. Kraków: Drukarnia Uniwersytetu Jagiellońskiego, lk 1-136.

Vakarelski 1977 = Вакарелски, Христо. Етнография на България. Второ издание. София: Наука и изкуство.

Wasilewski, Jerzy S. 1989. Tabu a paradygmaty etnologii (rozprawa habilitacyjna). Warszawa: Uniwersytet Warszawski.

Wierzchowski, Z. 1890. Materyjały etnograficzne z powiatu Tarnobrzeskiego i Niskiego w Galicyi. Zbiór wiadomości do antropologii krajowej 14. Kraków: Drukarnia Uniwersytetu Jagiellońskiego, lk 145-211.

Wójcicki, Kazimierz Władysław 1972. Klechdy, starożytne podania i powieści ludu Polskiego $i$ Rusi. Zebrał i spisal K. W. Wójcicki, wybór i opracowanie Ryszarda Wojciechowskiego, słowo wstępne Juliana Krzyżanowskiego. Warszawa: Państwowy Instytut Wydawniczy.

\title{
Summary
}

\section{On the Methods of Constructing a Mythological Text: Slavic Folk Beliefs regarding the Spots of the Moon}

\author{
Aleksandr Gura
}

Keywords: lunar spots, mythology, Slavic folklore

The dark spots visible on the surface of the full Moon have been diversely interpreted in the Slavic folk calendar, with a partial overlapping being noted upon the consolidation of relevant thematic groups. The article provides an overview regarding the explanations, concerning the origin of lunar spots, widespread among the Slavic people. The comparative analysis of the Slavic narratives on lunar spots indicates the distribution of the text into different morphological elements, enables the ascertaining of mutual correlations and combinations, and shows how they are being used to "assemble", construct texts in different regional traditions, determining the "grammatical" structure of the mythological text as a whole. 